\title{
Determinants of Ecotourism Trade in Cameroon
}

\author{
Grace L. Sama1, Ernest L. Molua² \\ ${ }^{1}$ Faculty of Agriculture and Veterinary Medicine, University of Buea, Cameroon, Buea, SWR, Cameroon \\ ${ }^{2}$ Centre for Independent Development Research, Buea, SWR, Cameroon \\ Email: cidr@cidrcam.org
}

How to cite this paper: Sama, G.L. and Molua, E.L. (2019) Determinants of Ecotourism Trade in Cameroon. Natural Resources, 10, 202-217.

https://doi.org/10.4236/nr.2019.106014

Received: April 10, 2019

Accepted: June 24, 2019

Published: June 27, 2019

Copyright (C) 2019 by author(s) and Scientific Research Publishing Inc. This work is licensed under the Creative Commons Attribution International License (CC BY 4.0).

http://creativecommons.org/licenses/by/4.0/

\begin{abstract}
Trade in services accounts for a large and growing share of both production and employment in Cameroon. Services have been among the fastest-growing components of Cameroon's trade portfolio in sectors like telecommunications, information and communication technology, finance, transport and construction. Cameroon is endowed with potentials in the provision of services such as tourism, particularly ecotourism. However, the development of ecotourism still appears to be in its infancy. The country is still short of the objective to qualify as a developed tourism destination by the World Tourism Organisation standards. This raises important policy research questions. This paper examines the ecological assets and investigates the determinants of ecotourism in Cameroon; using an annual panel data of both primary and secondary data to analyse the economic, social, psychological and political impacts of ecotourism on local communities. The results revealed that the income of the origin countries, the price and the supply of available amenities in Cameroon significantly affect the demand for ecotourism services from Cameroon. The paper concludes that ecotourism has double-barrel potential to promote trade growth and enhance the welfare of local communities.
\end{abstract}

\section{Keywords}

Cameroon, Services Trade, Tourism, Ecotourism, Welfare Enhancement

\section{Introduction}

Tourism, according to the World Tourism Organization of the United Nations (UNWTO), takes place when people travel to and stay in places outside their usual environment for no more than one consecutive year for leisure, business and other purposes. This industry has become very important in contemporary 
society as it has performed remarkably well over the past few decades; substantially promoting growth in the world economy [1]. Over the past few decades ecotourism, which is a form of sustainable tourism, has also been acknowledged as one of the fastest-growing tourism market segments in various countries within sub-Saharan Africa [2] [3]. Reference [4] notes that ecotourism is a better strategy for local community development and management because it has the potential to alleviate the negative effects of mass tourism. Ecotourism is an important tool for economic diversification as it may reduce over dependence of agriculture in the rural communities to other profit-making ventures like community-owned game farming or sustainable collection of forest resources. In the long run, these local communities are more likely to support tourism and conservation as it is evident in Sankuyu [5], Khawa [6], Okavango Community Trust [5], and Basarwa communities in Botswana [7] (Mbaiwa, 2008). The contribution of ecotourism is not only well-known about its conservation in natural areas [8] [9] [10] [11] [12]; but also a means for income and employment opportunities in the rural communities in developing economies like Sub Saharan Africa.

In Cameroon, services trade is the fastest-growing sector, as it grew from less than $15 \%$ of the Gross Domestic Product (GDP) in the mid-1990s to more than $20 \%$ in 2000 [13]. The sector makes an enormous contribution to GDP and employment, since its share of the GDP has continuously grown since 1990. The average annual growth rate of services was up to $5 \%$, the highest of all other sectors in Cameroon [14]. Tourism and travel-related services contribute massively to the services sector in Cameroon, about $43.1 \%$, hence the buoyancy of the sector (ibid). This recent trend has attracted the attention of economists to understand if tourism can actually represent a key-sector for economic growth and sustainable development in developing countries (ibid). According to the World Travel and Tourism Council, the future of the industry is promising. Reports of WTTC show that the total investment in the tourism industry has gradually increased over the years (2000 to 2017) even though it dropped in the past two years [15]. Tourism and Travel investment in 2011 was 48.5 bn FCFA (2.3\% of total investment), which slightly reduced the following year. In 2016, its contribution rose to 682.1 bn FCFA (3.7\% of GDP) with an expected rise by $5.3 \%$ pa to 1204.5 bn FCFA (3.8\% of GDP) by 2027 as shown in Figure 1.

The contribution from the tourism industry in Cameroon reflects the economic activity generated by industries like hotels, travel agencies, airlines and other passenger transportation services which does not include commuter services [15]. The activities of the restaurant and leisure industries which are directly supported by the tourists are also included during data collection. Visitor exports is considered as one of the main components of direct contribution to the industry. In 2016, 374.6 bn FCFA in visitor exports was generated in the economy of Cameroon which generated a forecast to total 1,679,000, generating expenditure of 645.3 bn FCFA, an increase of $5.2 \%$. Unfortunately, with the cur- 
rent situation of the on-going "Anglophone Crises" which has plagued the country for the past three years, these forecasts would hardly be realized since most embassies advice potential tourists against taking trips to certain parts of Cameroon like the North, South West and North West regions of the country. Figure 2 represents visitor exports and international tourist arrivals as shown below.

More jobs have been created in the tourism industry in Cameroon over the recent years which has increased productivity and increased contribution to the GDP of the country. In 2011, 100,500 jobs directly generated by the industry ( $2.2 \%$ of total employment); which led to a $2.6 \%$ contribution to the GDP of the country [15]. This was greatly improved in 2016 as travel and tourism directly supported 289,500 jobs (3.1\% of total employment). This is further increased to $7.1 \%$ of total employment $(658,500$ jobs) by jobs which are indirectly related to the industry as 2017 reports of the WTTC show. This implies that, over the past two decades, tourism activities in Cameroon have been expanding rapidly, with 2016 recording the highest values; and further growth is expected in the future.
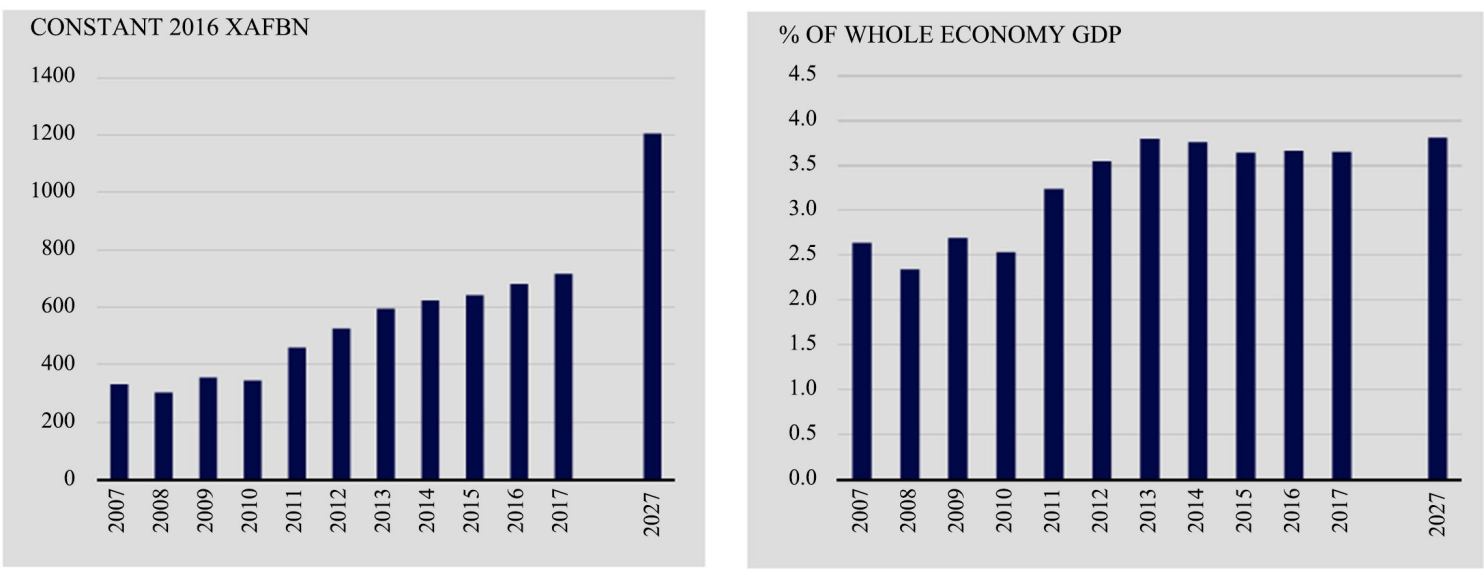

Figure 1. Direct Contribution of Travel and Tourism to GDP. Source: WTTC (2017) [15].
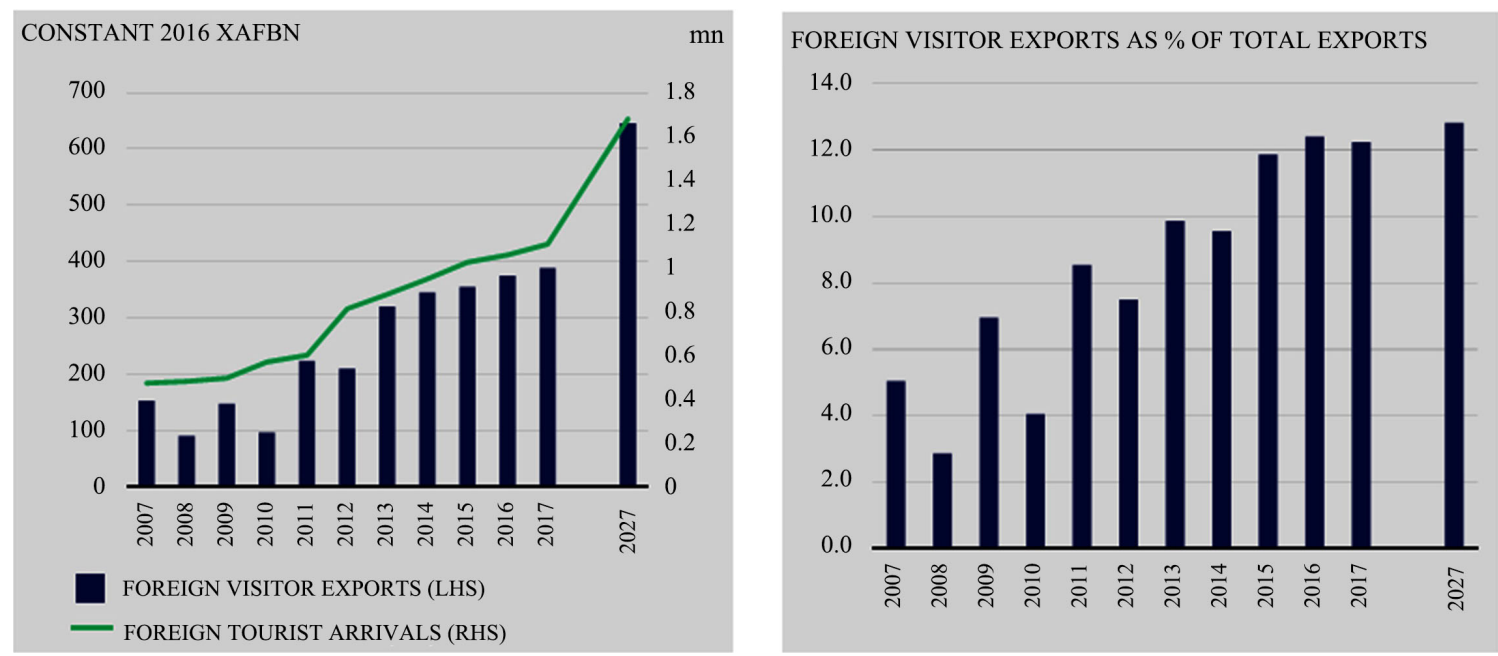

Figure 2. Cameroon visitor exports and international tourist arrivals. (Source: WTTC, 2017) [15]. 
Tourism in LDCs like Cameroon is still limited: $2.6 \%$ of the world market share in terms of international tourist arrivals (ITAs) and of international tourism receipts (ITRs) according to statistics [16] (UNWTO, 2011). It is worth noting that the growth in ITAs has been faster in LDCs than in the developing countries as a whole: $42.5 \%$ in the former and $30.8 \%$ in the latter between 2001 and 2005 (15.8\% for the world); while for ITRs: $50.3 \%$ growth has been recorded in LDCs and 40.6\% in the developing world between 2001 and 2004 (33.2\% for the world) (ibid). Cameroon, like most developing countries account for even dismal figures of 176,372 tourist arrivals in accommodation establishments down from the 247,578 recorded in 2001 according to the 2007 trade policy review report of the WTO (WTO, 2008). There were little improvements of 573,000 tourist arrivals shown in latest estimates of the ministry of tourism for 2010 [17].

Contrary to what the glowing picture of the travel and tourism sector in Cameroon has shown above, ecotourism in Cameroon is currently still premature and not formalized despite its label as an ecotourism paradise by some visitors. The country presents every visitor with diversity in natural (mountains, forests, tropical rivers, lakes, and climates) and cultural attractions (folklore, elaborate festivals, enduring kingdoms, and tales) created by about 250 ethnic groups; from the forested, coastal south and southeast to the Sahelian north. The availability of these resources illustrates Cameroon's ecotourism potential [18]. However, very little has ever been done by the state to formalise the ecotourism sector in Cameroon to reap its accrued benefits mainly due to state incapacity, centralization and lack of an effective national strategy for ecotourism. With all its considerable potential, the contribution of ecotourism to the country's growth and hence the fight against poverty, remains insufficient. The main problems relate to governance, the poor quality of hotel management, insufficient formal training, infrastructure, and deficient or obsolete equipment, the high cost of air transport, and the absence of promotion and information activities [19]. This nature-based tourism asset of the state has not received enough financial support and priority compared to the huge capital that the government continues to invest in economic and cultural tourism [20]. How then can the state promote ecotourism services trade and reap the benefits as well as minimize potential risks? The goal of this paper is to examine the determinants of ecotourism services trade in the Republic of Cameroon in order to harness the benefits that accrue to the enhancement of the sector. The benefits of ecotourism surpass that of traditional tourism as ecotourism is based on the conservation of depleting natural resources and improves the well-being of the local people. Although the significance of the ecotourism sector in Cameroon is widely recognized and much has been written about this sector, little attention has been given to explain systematically its determinants.

\section{Materials and Methods}

\subsection{Theoretical Framework}

Ecotourism is inspired primarily by the natural history of an area, including its 
indigenous cultures. The ecotourist visits relatively undeveloped areas in the spirit of appreciation, participation and sensitivity. Ecotourists practice a non-consumptive use of wildlife and natural resources and contribute to the visited area through labour or financial means aimed at directly benefiting the conservation of the site and the economic well-being of the local residents [21]. Ecotourism according to TIES (1990) is about "uniting conservation, communities, and sustainable travel." The ecotourism sector primarily consists of a collection of small and medium local business enterprises, local communities, and NGOs that develop and implement ecotourism programmes [22]. For ecotourism to be successful there are some vital aspects that should be considered. First of all, the local and international ecotourism stakeholders should be dependent on the state (Ministries of Tourism, Forestry, Environment, etc.) and partner to jointly develop policies that will protect and manage natural areas. This will facilitate proper implementation of these policies. The reputation and brand recognition of a country are very important in this industry hence the government and ministries have the responsibility to promote the image of that country as an ecotourism destination.

There is a large body of empirical literature that focuses on the determinants of ecotourism, although there are hardly any econometric studies that specifically focus on the determinants of ecotourism into Cameroon. According to [23], human resources through local community involvement is an important determinant to the success of ecotourism. In line with this, attractions (uniqueness, sights, scenes, environmental quality) signify the main areas of attention for the visitor and can be natural or man-made, which may be publicly or privately owned. The Centre for Responsible Travel asserts that the demand for ecotourism is increasing as tourists are more interested in the promotion and development of sustainable practices while they travel (Miller, 2017). Previous studies of the determinants of ecotourism are discussed in the subsequent paragraphs.

It has been empirically proven that the demand elasticity for international ecotourism varies by country of origin and country of destination [24]. In this light, [25] Witt and Witt (1995) assert that the demand for tourism is a function of the tourist's country of origin, since cultural differences affect travel behaviour (ibid). From the 1990s, a lot of variables have been used to explain the demand for ecotourism. According to [26], the discretionary income (income remaining after spending on necessities) of the origin country is the most appropriate measure of income in the demand for ecotourism, since it is considered to be a leisure activity. Because this variable is subjective, the GDP per capita will be used in this work as a proxy for purchasing power. Alternatives to this include the real private consumption expenditure [27], and the industrial production index [28].

The relative price between the origin country and the destination is another important determinant of ecotourism demand. This is because ecotourism is a consumption good and has its own price differentiated along different compet- 
ing places of destination [29]. For most studies, the price considered is the relative price between the receiving and sending country, adjusted by the bilateral exchange rate [30]. In some studies, the ratio of the consumer price index (CPI) is used; although most recently the real effective exchange rate is used [31]. Other studies talk about the importance of the price factor and the discretionary income of the eco-tourists, but not much was mentioned about cultural differences which greatly affect travel behaviour. Other commonly used variables include transportation costs, tourism shocks and supply factors. More important to consider which is not usually found in most tourism-related empirical literature is the effects of variables that vary over time on ecotourism demand; as ecotourism supplies not just the product but the host country, making it more sensitive to factors like ethnical tensions and external conflicts.

Empirical studies based on ecotourism are divided into two broad groups; those adopting the time series co-integration method and those that apply cross-sectional (panel data) Ordinary Least Squares techniques for a limited number of countries around the world. However, the time series method is hardly used because even though they are useful tools for tourism demand forecasting, they cannot be used for policy purposes since they are not based on the theory that underlines the tourist's decision-making process [32] (Naudé and Saayman, 2005). With panel data, the behaviour of entities is observed across time which is very important in ecotourism analyses as past experiences have a significant effect on future demand; and has been applied in this work.

The determinants of tourism demand in African countries in general, have been explored over the years with a plethora of methods. The author in [33] employed the dynamic panel data model to test for convergence in Asian countries, and the results illustrated the importance of tourist arrivals on economic growth. Thus it was concluded that the tourism sector could be considered a determinant factor of economic growth. Some authors acknowledged the importance of tourism on economic growth and have analysed the determinants of tourist arrivals [33] [34] [35] by adopting both cross-section data and panel data for the period 1996-2000. Political stability, tourism infrastructure, marketing and information, and the level of development at the destination are key determinants of travel to Africa; according to the results.

\subsection{Study Area}

The Republic of Cameroon encompasses 47.5 million hectares of land area spanning 10 degrees of latitude just north of the equator. Forest and woodlands cover 60 percent of the national territory with more than half of this figure representing tropical moist forests. Among African countries, Cameroon ranks second only to Zaire in diversity of forest-dwelling primates, and among the top five in diversity of plant species [36]. The wildlife, composed of its flora and fauna, varies with the countries diverse ecologies. The wealth of its wildlife is embedded in the highlands and forests, covering an area of 38,000 square kilo- 
meters (14,700 square miles) in eastern Nigeria and western Cameroon [36] (LWC, 2012). The eco-region lies above 900 meters elevation, and is surrounded at lower elevations by the Cross-Sanaga-Bioko coastal forests at the southern end of the range, and by forest-savanna mosaic along the central and northern ends of the range; the Cameroon Highlands form the boundary between the Guinean and Northern Congolian forest-savanna mosaic ecoregions (ibid). The vegetation varies with elevation. Sub-montane forests extend from 900 to 1800 meters $(3000$ to $6000 \mathrm{ft}$ ) elevation. Above 1800 meters $(6000 \mathrm{ft})$ elevation are distinct montane forests and patches of montane grassland, bamboo forest, and sub-alpine grasslands and shrub-lands. The eco-region is characterized by the presence of afro-montane species, which have an archipelago-like distribution across the highlands of Africa. Typical afro-montane species are Nuxia congesta, Podocarpus latifolius, Prunus africana, Rapanea melanophloeos, and Syzygium guineense bamendae [37].

The country's wildlife wealth in its flora and fauna, varies with the country's diverse ecologies and is rich in plant species. Among the wildlife are primates and other large mammals, many of which are listed by the International Union for Conservation of Nature and Natural Resources (IUCN) as rare, endangered or threatened with extinction [38] (MINEPIA, 2012). These include the Cross River Gorilla (Gorilla gorilladiehli), an endemic subspecies of Western Gorilla, Mainland Drill (Mandrillus leucophaeus leucophaeus), Preuss's guenon (Cercopithecus preussi), Preuss's Red Colobus (Pilocolobus preussi), and Common Chimpanzee (Pan Troglodytes). Nine species of reptiles and 40 species of amphibians are endemic to the eco-region as well [39]. Several geological, historical, and climatic factors contribute to the exceptional diversity of Cameroon's biota and to its potential endangerment. The botanical richness of the southern littoral forests of Cameroon and Mount Cameroon is thought to result from the isolation of these areas as Pleistocene "refugia." Remnants of the rich Guinea-Congolean forest biota survived here during periods of dry climate when the range of tropical moist forests contracted elsewhere [20]. Mount Cameroon and the Mount Kilum and Mount Kupe regions of the western highlands retain montane relict species (particularly forest birds, bamboo and other vascular plants) which are endemic to the region but show ancient affinities to afro-montane elements of eastern Africa. These may reflect links to cooler and wetter conditions than those occurring in the region today [20].

\subsection{Analytical Framework}

The model for specification in this study is based on the classical economic theory which assumes that income and price factors constitute an important role to determine the demand for ecotourism [30]. However, this model will be modified to reflect the reality in Cameroon and to specifically deal with ecotourism by including non-economic factors like tourism shocks (political instability, natural disasters, and lack of related institutions) as these are all very important 
determinants [8] [40] [41]. Hence a causal, econometric techniques model is adopted in this study to identify and measure both economic and non-economic variables affecting other variables such as price and quantity. In addition to these, a number of studies have examined the factors influencing inflow of tourists into various destinations and this study disaggregates the data on international arrivals into the purposes of travel and the various originating regions. Thus, based on the work of [1], the model specification is

$$
\mathrm{ET}=f(\mathrm{WY}, \mathrm{ER}, \mathrm{PI}, \mathrm{CP})
$$

where ET is eco-tourists (eco-tourist arrivals); WY is world income (represented by the top ten originating destinations: France, China, USA, Germany, Belgium, Canada, Italy, Switzerland, Britain, and Holland); ER is exchange rate; PI is public infrastructure network; and CP is civil liberties and political rights.

The most common specifications used for estimating the demand function of tourism are linear and log linear functions. The log-linear form is popular because of the straightforward interpretation of the parameter estimates and this will also be used in this work. In a review article, [25] conclude that $75 \%$ of the analysed models used a double log functional form, $18 \%$ a linear specification and the remaining are probit-logit models or semi-log specifications [30]. According to them, double log specification presents more satisfactory estimation results obtained and easier to interpret the estimated coefficients through the demand elasticities [1]; which will be applied in this work. Considering the non-linear $\log$ form of equation 1 , the equation can be econometrically written as;

$$
\ln \mathrm{TA}=\alpha 0+\alpha 1 \ln \mathrm{WY}+\alpha 2 \ln \mathrm{ER}+\alpha 3 \ln \mathrm{CP}+\alpha 4 \ln \mathrm{PI}+\pi
$$

where TA is eco-tourists (eco-tourist arrivals), WY is world income (represented by the top ten originating destinations: France, China, USA, Germany, Belgium, Canada, Italy, Switzerland, Britain, and Holland), ER is exchange rate, PI is public infrastructure network, $\mathrm{CP}$ is civil liberties and political rights and $v$ is the error term. It is very important to note that a market is a given origin country in a given year. Thus, the independent variables depend only on that particular origin at that same year ( $\mathrm{t}$ ), but do not vary across destinations. Therefore, it can be interpreted as affecting the utility level of the tourists. This means that, the aim of this study does not explain variations in the propensity to travel, hence the year and origin fixed effects is included in all the specifications of this work.

The most popular method of estimation is the Ordinary Least Squares (OLS) which is usually found in the analysis of traditional tourism demand. References [35] and [25] assert to this fact based on their studies which revealed that up to $75 \%$ of the paper used the OLS estimation that involves static data. The setback of adopting this method is that, most tourism demand (in this case, ecotourism) data are non-stationary and this has been overlooked by most researchers. This makes the estimated parameters unreliable, the t-tests and F-tests to produce misleading results, including structural and forecasting problems (ibid). To 
overcome these limitations, the cointegration method was introduced to cater for dynamic methodologies in the field of tourism. Cointegration shows the long-run equilibrium relationship while accommodating the dynamic short-run relationship [30].

\subsection{Nature and Source of Data}

Secondary data is to be employed covering the period 1980-2012. Most sub-Saharan African countries like Cameroon have historical experiences on tourism that date back to 1900s. Information on the parameters is obtained from the Ministry of Tourism in Cameroon, World Tourism Organisation, World Bank, UNCOMTRADE, Index Mundi, and the PENN World Tables and even generated by the author. The data on eco-tourist arrivals was generated by the author based on related reports and from similar economies. This may make results faulty since each country has unique characteristics. However, the error term in the model minimises such errors and the estimates computed are as close to reality as possible.

The variables used in this work are eco-tourist arrivals (dependent variable), the GDP of the origin countries selected, the REER of Cameroon, the ratio of public investment to GDP of Cameroon and the political environment of the country. The dependent variable is the number of eco-tourist arrivals into Cameroon; since it is almost impossible to get data on eco-tourist expenditure, and number of eco-tourist nights in the host country. This is most probably the most reliable measure of the demand for tourism in Cameroon [24] [25].

The independent variables include the Real Gross Domestic Product per capita (GDP) of the origin country represents the level of income of that country. Since eco-tourism is usually considered a luxury service, it therefore means that countries with higher GDP per capita have a higher propensity to consume this service than those with lower GDP per capita. The Real effective exchange rate is also tested and captured as the nominal effective exchange rate (a measure of the value of a currency against a weighted average of several foreign currencies) divided by a price deflator or index of costs. This variable represents the price factor as the selection of a price variable is particularly difficult. In most studies, tourism prices were described as costs of living in the host country by the tourists from the origin countries. Thus the consumer price indices were used as a proxy for the cost of tourism in destination relative to the cost of living in the origin country adjusted by the exchange rate [42] [43].

Tourism shock is studied. To account for the effect of some shocks that might have a transitory influence on eco-tourism demand, dummy variables are frequently used. Some examples of these dummy variables are political instability and social conflict, terrorism, travel restrictions, oil crises, world fairs and sporting events [30]. In this study, the political component is represented by a variable to capture the effect of political rights and civil liberties on tourist inflows [1]. The indices of the political component rate countries based on the 
scale of 1 to 7 , where 1 represents the highest degree of civil liberties and political rights and 7, the lowest. In this work, factors that are considered in the measurement of civil liberties and political rights include electoral process, political pluralism and participation, functioning of Government, freedom of expression and belief; associational and organizational rights; rule of law; personal autonomy and individual rights [1]. Thus it is assumed that improving these factors may enhance the image and attractiveness of the host nation to international tourists and vice versa.

Although the inclusion of supply factors is rare in estimating ecotourist arrivals, it is very important in this work since the availability of these factors is extremely important in the case of eco-tourism in developing countries. Two supply factors (accommodation capacity and public investment as a ratio to GDP) were used in [29] to estimate tourism inflows to Portugal, but were later revealed that only accommodation capacity is important (elasticity of 1.3). However, the public investment as a ratio to GDP will be used in this work to represent the public infrastructure network.

\section{Results and Discussion}

\subsection{Contribution of Tourism to the Economy of Cameroon}

Tourism has huge important economic impact in most countries around the world. In Cameroon, visitor exports have been gradually increasing while the contribution of tourism to the country's GDP has been on the rise over the past decades as illustrated in Figure 3. The direct contribution to GDP implies not only government like museums and other recreational activities like national parks; it involves total spending in Cameroon by residents and non-residents for business and leisure purposes. Data is compiled from sectors that deal directly with tourists like hotels, airlines, airports, travel agents and leisure and recreation services. Visitor exports means spending by foreign visitors. It is an essential component of trade because it significantly contributes to overall export revenues in Cameroon and around the world.

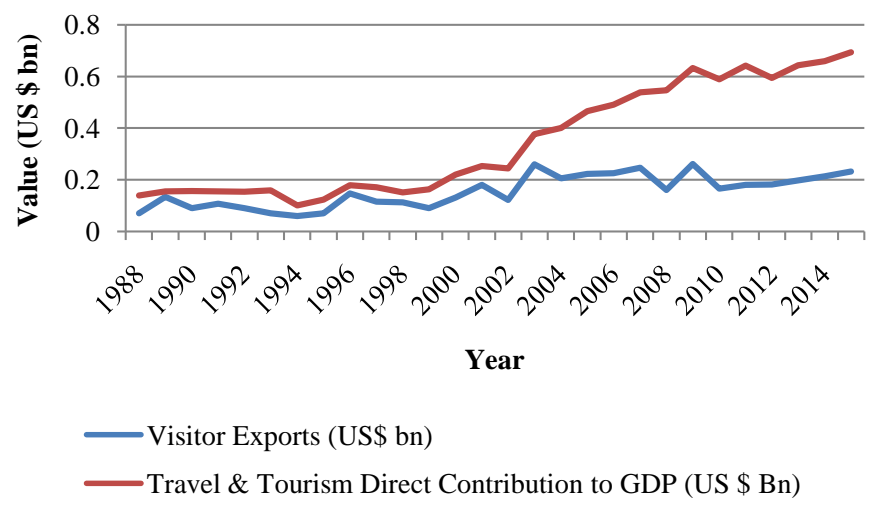

Figure 3. Contribution of Tourism to the Economy of Cameroon. Source: National Institute of Statistics (2016). 
Compared to other key sectors of the economy the tourism industry is performing better and according to global reports, in 2004, eco-tourism was growing globally 3 times faster than the tourism industry as a whole. This is true for Cameroon because most of the tourism that takes place in Cameroon is nature-based eco-tourism. It is based on the factsheet of TIES that data for eco-tourist arrivals will be generated since much of the data on eco-tourism is almost impossible to find.

Although tourism spending yields an impressive economic benefit as shown in Figure 3, ecotourism yields much more for the local communities if it is efficiently formalised through a joint partnership between the public and private stakeholders in the sector. An important aspect to note is sustainability of this sector and local community participation throughout the stages of conception, implementation and management of this sector in Cameroon. The benefits of eco-tourism may surpass that of traditional tourism as ecotourism is based on the conservation of depleting natural resources and improves the well-being of the local people.

\subsection{Determinants of Eco-Tourism Trades}

According to reports from the Ministry of Tourism, eco-tourism in Cameroon is a growing and relatively large industry. Eco-tourism is important in Cameroon, but the country has been unable to fulfill its enormous potential. According to the expectations made in the country's vision 2035, emphasis will be made on the establishment of an institutional and regulatory framework conducive to tourism promotion on the one hand, and improvement of the quality of tourist provision [13]. This would be done through 1) capacity building to enhance knowledge of tourist areas (including new areas like eco-tourism and cultural tourism) in which the country has a comparative advantage in. 2) Upgrading tourist sites and areas. 3) Developing tourist sites. 4) Promoting Cameroon as an eco-tourism destination.

As shown in Table 1, based on the data sample, estimates show that $59 \%$ of the changes in the demand for eco-tourist arrivals in Cameroon are explained by the independent variables. The results of the GDP of Origin Countries are highly significant and the positive sign of the coefficient depicts the direct relationship between the purchasing power of the eco-tourists and the demand for ecotourism services. This means that as the GDP increases in the country of origin, the demand for ecotourism services from Cameroon increases. The Real Gross Domestic Product (GDP) per capita (purchasing power parity) of the origin country represents the level of income of that country. It was expected that the estimated coefficient of this variable will be positive since it is assumed that as the income of the origin country increases, the number of tourist arrivals in Cameroon by that country's residents will increase. In addition to this, since ecotourism is usually considered a luxury service, it therefore means that countries with higher GDP per capita have a higher propensity to consume this service than those with lower GDP per capita. 
Table 1. Econometric Long-run Estimates of Eco-tourists into Cameroon.

\begin{tabular}{ccc}
\hline Variables & Coefficients & t-statistics \\
\hline $\begin{array}{c}\text { Gross Domestic Product per capita } \\
\text { of Countries of Origin (GDP) }\end{array}$ & 1.62 & 6.99 \\
$\begin{array}{c}\text { Real Effective Exchange Rate (REER) } \\
\text { between origin country and host country. }\end{array}$ & 0.77 & 2.84 \\
Public Investment to GDP ratio & -0.11 & -2.08 \\
\hline
\end{tabular}

Notes: $\mathrm{F}(4,28)=12.55, \mathrm{R}^{2}=0.64$, Adjusted $\mathrm{R}^{2}=0.59, \mathrm{n}=33$, Source: Authors' computation.

The Real Effective Exchange Rate (REER) is statistically significant at a 95\% confidence level with a positive coefficient. This means that due to the devaluation of the CFA francs (pegged to the French Franc) in 2002, the CFA francs became cheaper. This increases its demand and then in the long run, the price increases; which explain the positive relationship. The Real effective exchange rate was the nominal effective exchange rate (a measure of the value of a currency against a weighted average of several foreign currencies) divided by a price deflator or index of costs. This variable represents the price factor as the selection of a price variable is particularly difficult. In most studies, tourism prices were described as costs of living in the host country by the tourists from the origin countries. Thus the consumer price indices were used as a proxy for the cost of tourism in destination relative to the cost of living in the origin country adjusted by the exchange rate [43]. The sign of the coefficient of this variable was expected to be positive due to the effects of the devaluation of the CFA francs on the exchange rates and the demand for the currency.

Amenities or supply factors show an interesting relationship with eco-tourist arrivals. The ratio of investment to GDP is statistically significant and the negative coefficient signifies that an increase in government spending in the ecotourism sector will lead to a fall in the demand for the services provided. The efficiency of this sector entails local community and private sector participation. This is because of completion and the efficiency of production, hence limited government intervention is required. In most tourism-related empirical literature, ecotourism is only successful when conservation takes place with local participation and empowerment, aspects which significantly differentiate this form of tourism from traditional tourism. Reference [44] asserts that eco-tourism is a more sustainable way to protect the natural environment and create socioeconomic, cultural and ecological benefits for local communities. It is worth noting that despite this, eco-tourism when poorly planned and implemented can quickly turn gains into social and environmental disaster [32]. This is most probably the main reason why Cameroon is unable to fully explore the potentials to complement the state's tourism demands and pursuits. In addition to this, the national parks lack facilities and are not well developed to meet international standards and to attract foreign arrivals as expected. These could among other factors be attributed to the lessened attention government and cooperate indi- 
viduals accord to this sector.

The results obtained are explained by the nature of the economic and political factors. For example, the CFA franc was pegged to the French franc, and now to a stronger euro which contributed to the REER's appreciation over the years [45]. However, between 2010 and 2011, the REER depreciated by about 7\% as the euro depreciated against major foreign currencies; even though the depreciation did not offset the cumulative appreciation of the REER in 1994-2009 of $24 \%$ [46]. Government spending in Cameroon has not changed much. Improvements would contribute positively towards the ecotourism sector, especially if this is geared towards the sector as it is done towards other tourism sectors (like cultural tourism) within the industry. Despite its considerable potential, the contribution of eco-tourism to the country's growth and hence the fight against poverty, remains insufficient [14]. The main problems relate to governance, the poor quality of hotel management, lack of training, infrastructure, and insufficient or obsolete equipment, the high cost of air transport, and the absence of promotion and information activities [19]. This nature-based tourism asset of the state has not received enough financial support and priority compared to the huge capital government continues to invest in economic and cultural tourism.

The Political environment in Cameroon was also considered as an important determinant since the country also supplies itself during the provision of the services rendered to eco-tourists. The political environment of Cameroon has been relatively stable over the years. Political stability is also a very important pull factor. Even though according to recorded data the indices used to measure this factor have not been favourable, Cameroon is actually one of the most politically stable countries in Western and Central Africa; and even in the continent as a whole. Over the years, Cameroon has portrayed a relatively calm atmosphere which is favourable for both tourists and investors; hence, more should be done in this light to attract foreign direct investment into the country. Unfortunately the past two years have not been the same in terms of political stability of the country. The advent of the current Anglophone crises has led to huge loss in terms of tourism-related revenue and tourist arrivals and some embassies are known to have cautioned their citizens against visits to Cameroon.

\section{Conclusion}

Ecotourism in Cameroon is still in its infancy and the government is yet to invest as much as it does in other sectors of the tourism industry. The over dependence of agricultural and oil exports has reduced the country's exports since most of its neighbouring countries also have similar exports (low intra-regional trade). Cameroon has a comparative advantage in ecotourism not just because of its ecological assets but also to a recorded politically stable environment relative to its politically turbulent neighbours (Nigeria, Congo). The econometric results revealed that the GDP of the origin countries, the REER of Cameroon and the ratio of public investment to GDP in Cameroon significantly affect the demand 
for ecotourism services from Cameroon. However, the signs of their coefficients differed with what was expected as that for the REER was positive and that for the ratio of public investment to GDP was negative. Thus, knowledge of the determinants of ecotourism demand could facilitate policy makers to design appropriate strategies to further develop this sector in Cameroon. However, it is worth noting that ecotourism by itself is not a panacea. There are so many factors that should be put in place for the success of this sector because in the absence of these factors, the resulting ventures may alienate, rather than benefit the local communities if business is the main driving force behind ecotourism.

\section{Conflicts of Interest}

The authors declare no conflicts of interest regarding the publication of this paper.

\section{References}

[1] Bentum-Ennin, I. (2009) Determinants and Economic Impact of International Tourists' Arrivals in Ghana. AERC Working Paper. African Economic Research Consortium, Nairobi.

[2] Sidinga, I. (1999) Tourism in Sub-Saharan Africa. In: Reid, D.G., Ed., Ecotourism Development in Eastern and Southern Africa. University of Guelph, Weaver Press, Harare, 1-28.

[3] United Nations World Tourism Organization (2011) Tourism Highlights: 2011. UNWTO, Madrid.s

[4] Fennell, D. (2008) Ecotourism. TJ International Ltd., Padstow, UK.

[5] Snyman, S. (2014) Partnership between a Private Sector Ecotourism Operator and a Local Community in the Okavango Delta, Botswana: The Case of the Okavango Community Trust and Wilderness Safaris. Journal of Ecotourism, 13, 110-127. https://doi.org/10.1080/14724049.2014.980744

[6] Moswete, N., Thapa, B. and Lacey, G. (2009) Village-Based Tourism and Community Participation: A Case Study of the Matsheng Villages in Southwest Botswana. In: Saarinen, J., Becker, F., Manwa, H. and Wilson, D., Eds., Sustainable Tourism in Southern Africa: Local Communities and Natural Resources in Transition, Channelview, Clevedon, 189-209.

[7] Mbaiwa, J.E. (2008) Tourism Development, Rural Livelihoods, and Conservation in the Okavango Delta, Botswana. Unpublished PhD Dissertation, Texas A\&M University, USA.

[8] Page, S. and Dowling, R. (2002) Ecotourism. Pearson Education Ltd., Harlow.

[9] Diamantis, D. (1998) The Concept of Ecotourism: Evolution and Trends. CH-3975, Les Roches Management School, Tourism Research Centre, Bluche, Switzerland.

[10] Goodwin, H. (1996) In Pursuit of Ecotourism. Biodiversity and Conservation, 5, 277-291. https://doi.org/10.1007/BF00051774

[11] Kelkit, A., Celik, S. and Esbah, H. (2010) Ecotourism Potential of Gallipoli Peninsula Historical National Park. Journal of Coastal Research, 26, 562-568. https://doi.org/10.2112/09-1181.1

[12] Weaver, D.B. (2005) Comprehensive and Minimalist Dimensions of Ecotourism. Annals of Tourism Research, 32, 439-455. 
https://doi.org/10.1016/j.annals.2004.08.003

[13] MINEPAT (2009) Cameroun Vision 2035. Ministère de l'économie, de la Planification et de l'Aménagement du Territoire. Vol. I, Rapport Principal, Yaoundé, Cameroun, 22.

[14] World Trade Organization (2008) Trade Policy Review of Cameroon. WTO, Geneva.

[15] World Travel and Tourism Council (2017) Travel \& Tourism Economic Impact: Cameroon. WTTC, London.

[16] United Nations World Tourism Organization (2011) Tourism Highlights: 2011. UNWTO, Madrid.

[17] World Trade Organization (2014) Trade Policy Review of Cameroon. WTO, Geneva.

[18] Behrens, J. (2005) The Potential for Ecotourism in Cameroon-A Stakeholder Analysis. In: Lichtenberg, T.J., Ed., Beiträgezum Nachhaltigen Tourismus, Schriftenreihe der Fachhochschule Eberswalde, Mensch \& BuchVerlag, Berlin.

[19] United Nations World Tourism Organization (2010) Tourism Highlights: 2010. UNWTO, Madrid.

[20] MINEF (1996) Plan National de Gestsion de l'Environnement. Ministère de l'Environnement et des Forêts. Rapport Principal. Vol. 1, MINEF/PNUD/Banque Mondial, Yaoundé, Cameroon, 225.

[21] Ziffer, K. (1989) Ecotourism: The Uneasy Alliance. Conservation International, Ernst and Young, Washington, DC.

[22] TIES (2008) The Components of Successful Ecotourism. The International Ecotourism Society (TIES).

[23] Courvisanos, J. and Jain, A. (2006) A Framework for Sustainable Ecotourism: Application to Costa Rica. Tourism and Hospitality Planning \& Development, 3 , 131-142.

[24] Naudé, W.A. and Saayman, A. (2005) Determinants of Tourist Arrivals in Africa: A Panel Data Regression Analysis. Tourism Economics, 11, 365-391. https://doi.org/10.5367/000000005774352962

[25] Witt, S.F. and Witt, C.A. (1995) Forecasting Tourism Demand: A Review of Empirical Research. International Journal of Forecasting, 11, 447-475. https://doi.org/10.1016/0169-2070(95)00591-7

[26] Lim, C. (1997) Review of International Tourism Demand Models. Annals of Tourism Research, 24, 835-849. https://doi.org/10.1016/S0160-7383(97)00049-2

[27] Gonzales, P. and Moral, P. (1995) An Analysis of the International Tourism Demand in Spain. International Journal of Forecasting, 11, 233-251. https://doi.org/10.1016/0169-2070(94)00570-3

[28] Song, H., Wong, K. and Chon, K. (2003) Modelling and Forecasting the Demand for Hong Kong Tourism. International Journal of Hospitality Management, 22, 435-451. https://doi.org/10.1016/S0278-4319(03)00047-1

[29] Proença, S.A. and Soukiazis, E. (2005) Demand for Tourism in Portugal: A Panel Data Approach. Discussion Paper No. 29. Centro de Estudos da Uniao Européia, Coimbra, Portugal.

[30] Tsounta, E. (2008) What Attracts Tourists to Paradise? IMF Working Papers, Washington DC. https://doi.org/10.5089/9781451871357.001

[31] Ashley, C. (2000) The Impact of Tourism on Rural Livelihoods, Namibia's Expe- 
rience. Working Paper Overseas Development Institute, UK

[32] Buchsbaum, B.D. (2004) Ecotourism and Sustainable Development in Costa Rica. M.Sc. Thesis, Virginia Polytechnic Institute and State University, College of Architecture and Urban Studies, Virginia.

[33] Sica, E. (2005) Tourism as Determinant of Economic Growth: The Case of South-East Asian Countries. Working Paper.

[34] Saayman, A. and Saayman, M. (2008) Determinants of Inbound Tourism to South Africa. Tourism Economics, 14, 81-96. https://doi.org/10.5367/000000008783554893

[35] Crouch, G.I. (1995) Promotion and Demand in International Tourism. Journal of Travel and Tourism Marketing, 3, 109-125. https://doi.org/10.1300/J073v03n03_07

[36] LWC (2012) Annual Report, Limbe Wildlife Centre (LWC). Delegation of Tourism, Limbe, Cameroon.

[37] LBC (2012) Annual Report, Limbe Botanic Garden. Delegation of Tourism, Limbe, Cameroon.

[38] MINEPIA (2002) La Stratégie Sectorielle de l'élevage, des Pêches et des Industries Animales. Ministère de l'Elevage, des Pêches et des Industries Animales. Cameroun, 93.

[39] Baillie, J.E., Bennum, L.A., Brooks, T.M., Butchart, S.H., Chanson, J.S., Cokeliss, Z., Hilton-Taylor, C., Hoffmann, M., Mace ,G.M., Mainka, S.A., Pollock, C.A., Rodrigues, A.S.L., Statterfield, A.J. and Stuart, N. (2004) 2004 IUCN Red List of Threatened Species. A Global Species Assessement. IUCN, Gland, Switzerland and Cambridge, UK.

[40] Richter, L. (1989) The Politics of Tourism in Asia. University of Hawaii Press, Honolulu.

[41] Wang, Y. and Pfister, R.E. (2008) Residents Attitudes toward Tourism and Perceived Personal Benefits in a Rural Community. Journal of Travel Research, 47, 84-93. https://doi.org/10.1177/0047287507312402

[42] Ouerfell, C. (2008) Co-Integration Analysis of Quarterly European Tourism Demand in Tunisia. Tourism Management, 29, 127-137. https://doi.org/10.1016/j.tourman.2007.03.022

[43] Habibi, F., Abdul Rahim, K., Ramchandran, S. And Chin, L. (2009) Dynamic Model for International Tourism Demand for Malaysia: Panel Data Evidence. International Research Journal of Finance and Economics, No. 33, 207-217.

[44] Ofem, O., Lifu, F., Ogar, I., Eja, E. and Ajadi, B. (2012) Potentials of Developing the Cross River State National Park as an Ecotourism Resort, Nigeria. SAVAP International, 550-557.

[45] IMF (2007) Cameroon: 2007 Article IV Consultation. IMF Country Report No. 07/285.

[46] IMF (2012) Cameroon: 2012 Article IV Consultation. IMF Country Report No.12/237. 